\title{
INTELLECTUAL PROPERTY RIGHTS (IPR) SOCIALIZATION OF SASAK TRADITIONAL SOCIETY'S SUBHANALE WOVEN FABRIC IN CENTRAL LOMBOK
}

\author{
Emy HANDAYANI ${ }^{*}$, I.G.A. Gangga Santi DEWI² and Andri KURNIAWAN ${ }^{3}$ \\ ${ }^{1,2}$ Diponegoro University Semarang \\ ${ }^{3}$ State Islamic University of Mataram \\ *emyfhundip@yahoo.co.id
}

\begin{abstract}
This community service activity is motivated by the work of indigenous peoples in the form of Subhanale woven fabric that do not yet have intellectual property rights (copyright). With the progress of the times and the incessant amount of information, it is very necessary for the Sasak indigenous people to protect the works of indigenous peoples that already exist from generation to generation, so that this community service activity has the aim of (1) providing an understanding of the importance of maintaining their creations, (2) encouraging traditional society leaders and village officials to immediately register the intellectual property rights (copyright) of Subhanale woven fabric.This activity is a regulations socialization so that indigenous peoples know that the intellectual property rights (copyright) of their works can be protected by the government. It can be seen from the artworks owned by the Sasak people in the form of woven fabrics with the Subhanale pattern which are very popular with the public even from abroad. Because there is no intellectual property right (copyright) for the work, it is vulnerable to be claimed by other parties who are not entitled to it. The conclusion of this socialization activity received a positive response from the community, which was marked by understanding the copyright importance of their work and will immediately manage the intellectual property rights (copyright) with support from local academics and other related parties so that indigenous peoples get legal recognition of their artworks.
\end{abstract}

Keywords: IPR, Legal Protection, Sasak Tribe, Subhanale Woven Fabric

\section{BACKGROUND}

The results of traditional works in this archipelago are very diverse. From the diversity of these traditional works, which can be in the form of traditional fabrics with distinctive patterns, traditional clothes, weapons, and other traditional works. The Sasak people of West Nusa Tenggara, especially in the Sukarara village area, Jongat district, Central Lombok, have hereditary artworks in the form of songket woven cloth, which is commonly known as the Subhanale pattern. This Subhnale woven fabric is a hereditary work of the Lombok Sasak people who at the beginning of its creation were amazed by the creation of this pattern. The weavers repeatedly recite "subhanallah", "Glory be to Allah" due to their amazement, while working on the extraordinarily complex ancient patterns. So are the users. They spontaneously said "Subhanallah" when they saw the beautiful weaving of Lombok. From the admiration expression of the greatness of Allah, a pattern called Subhanale was born. The subhanale pattern is a geometric arrangement of hexagons like a honeycomb filled with flowers. This pattern is one of the ancient patterns in Lombok besides there are several patterns including 1). Subhanale Songket Penginang Fiber Pattern philosophically implies that every human must have an attitude of togetherness and harmony with each others, 2). Subhanale Woven Fabric Bulan Berkurung Pattern philosophically means that there is a God, every humans must always remember and grateful of the greatness of God, 3). Songket Subahnale Bintang Empat philosophically has a meaning related to the direction of the wind, which is inspired by the release of the eastern star in the morning. The eastern star appears is a sign that the sun will soon rise, 4). Subahnale Songket cloth Wayang Pattern has a philosophical meaning that humans in this world actually cannot live alone, but we really need other humans.

The complexity and beauty of the patterns are recognized worldwide. Although it has been much reduced for practical reasons, woven fabric in Lombok Island is still used in traditional ceremonies, such as in the ceremony of peraq api or puput of the baby's navel, berkuris (shaving the baby's hair), sorong serah aji krama (handing over woven fabric from the groom's family to the bride's family), and circumcision.

The results of this artwork have not been registered as Intellectual Property Rights, either in the government or in the customary group which in this globalization era Intellectual Property Rights on artworks is very important because patent rights are company assets, contain guarantees of legal protection, increase consumer trust, provide additional benefits, and can reduce plagiarism.

This Community Service in Sukarara Village, Jongat Sub-district, Central Lombok aims to provide counseling on the importance of patenting their copyrighted works that have existed hereditary as assets of their customary wealth, because from the side of indigenous peoples themselves they still do not care that their creations are an invaluable asset if it is claimed and plagiarized by other parties. This is our effort as academics to maintain and be obliged to protect the artworks of indigenous peoples in the archipelago from extinction and irresponsible claiming of those who are not the creators.

\section{Partner Problems}

The partners of this community service activity are 1) Mr. Sunardi as the head of the Sukarara village hamlet, 2) Mr. Jumarsee as the head of Sukarara village, and 3) Mr. Lalu Sukardi as the head of the Sukarara village customary institution 
The people of Sukarara Village have been trying to register intellectual property rights for their artworks but have not gotten what they expected due to the lack of knowledge and the reluctance of the management which they consider difficult for the Sasak people of Sukarara Village.

\section{METHOD}

This activity involves traditional leaders and village heads and their apparatus, traditional leaders, and heads of customary hamlets in the Sukarara village area as targets. This community service activity uses an approach method in the form of outreach to the community. The activity was carried out in the bale (traditional meetings place) with direct dialogue in a family manner about the importance of defending their works legally, especially their traditional works. It is hoped that after the implementation of this socialization activity, the society will understand that the rights of works must be protected by the government according to law.

The steps that have been carried out in this community service activity are as follows:

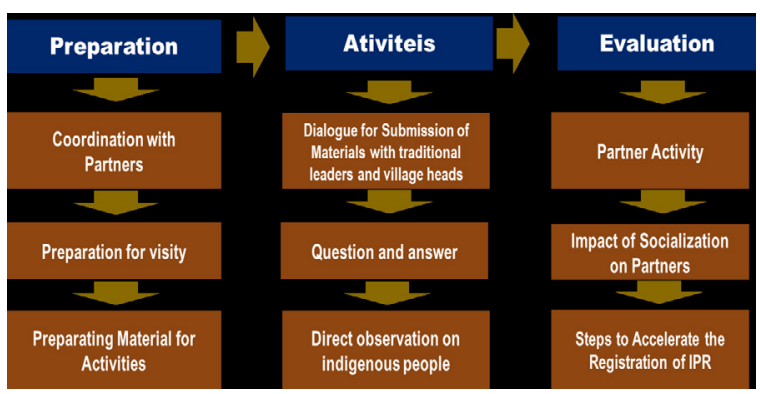

Figure 1. Stage Preparatioan, Activities, and Evaluation

\section{RESULTS AND DISCUSSION}

Implementation of Legal Counseling for the Sasak Indigenous People (Sukarara Village)

The legal counseling activity was attended by the Sukarara Village Head, hamlet head, and several customary head of the Sasak indigenous society, which amounts to 25 people. In carrying out this activity, the executors of this community service activities work closely with the village head of Sukarara and related traditional leaders. The activity was carried out in the form of a discussion held in a workshop. It was attended by 25 participants who came from traditional community leaders who incidentally had become one of the village officials, traditional leaders and the Sasak community. In the discussion, counseling was carried out by the executors of community service followed by a dialogue or question and answer. This counseling of Intellectual Property Rights knowledge provides an understanding to members of the Sasak indigenous group.

In accordance with Article 1 of the Copyright Law number 28 of 2014, Copyright is the exclusive right of the creator that arises automatically based on declarative principles after a work is realized in a tangible form without reducing restrictions in accordance with the provisions of laws and regulations. While in Article 1 of the Copyright Law number 28 of 2014, it is stated that "Creation is any copyrighted work in the fields of science, art, and literature produced on the inspiration, ability, thought, imagination, dexterity, skill, or expertise expressed in real form". Here it can be interpreted that the creation is the result of every work of the creator that shows idea authenticity in a person's artwork, namely in the form of subhanale weaving. The creator (in Article 1 of the Copyright Law number 28 of 2014) is "a person or several people who individually or jointly produce a creation that is unique and personal" which in this context is the Sasak indigenous people.

\section{Importance of Copyright Registration}

Law number 19 of 2002, Article 12 and Article 10 paragraph 2 Article 12 paragraph 1: "provide protection for copyrighted works in the fields of science, art and literature, for dance works mentioned in letter e" Article 10 paragraph 2 ; "The state holds the copyright on folklore and other people's cultural products, in this case it also includes traditional customary pattern art whose creators are not known in order to prevent monopolies or commercialization as well as destructive actions or commercial uses without the permission from the Republic of Indonesia as the Copyright Holder. This provision is intended to avoid the actions of foreign parties that can damage the cultural values.

Meanwhile, it is further strengthened by the Copyright Law number 28 of 2014 in article 40 paragraph 1 that "Protected creations include works in the fields of science, art, and literature" which in letter $\mathrm{j}$ is "works of batik art or other pattern art"

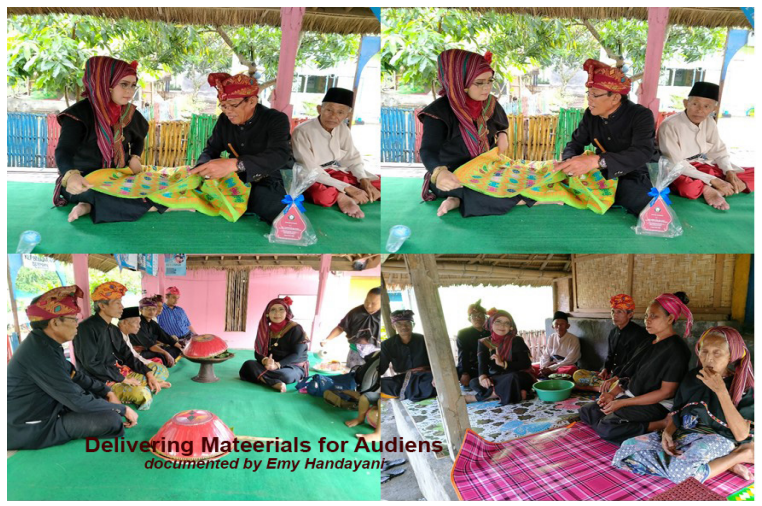

Figure 2. Delivering Material for Audiens

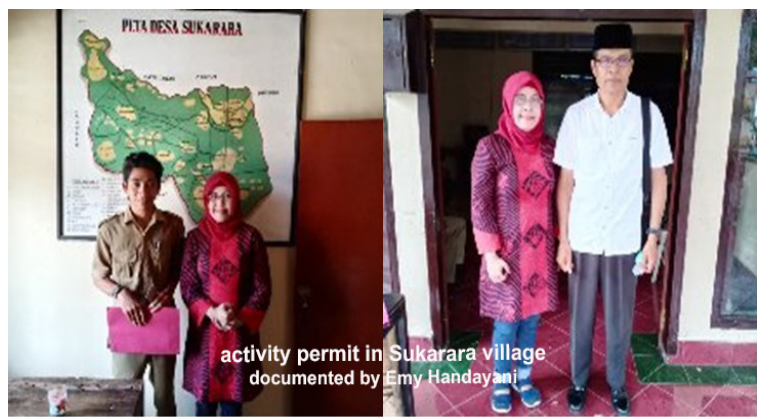

Figure 3. ActivityPermit in Sukarara Vilage 


\section{Basic Principles of Copyright}

1. What is protected by copyright is an idea that has been tangible and original

2. Copyright arises automatically

3. A creation does not need to be published to obtain copyright

4. A published or unpublished creation

5. Copyright of a creation is a right recognized by law that must be separated and must be distinguished from physical possession of a creation

6. Copyright is not an absolute right

\section{Philosophical Basis of Applicability of Copyright}

1. In accordance with the concept of property rights which are immaterial and are material rights. Material rights have the nature of droit de siut, namely always following where the object is located, so that the owner may take any legal action against his rights.

2. Limitation of the time of copyright ownership in the period of life plus 70 years, for the purpose of preventing the copyright from being held long in the hands of an author as the owner, so that after the author dies and is added 70 years, then the right can be enjoyed by the wider community freely as public property. It means that the public may publish or reproduce without having to ask permission from the creator or rights holder and is not considered a copyright infringement.

\section{Purpose of Copyright Law}

1. Channeling individual creativity for human benefit because the creations of artists are not legally respected by the society and the artists themselves. It is caused by Intellectual Property Rights as a legal institution are not felt to be able to protect the legal necessity of artists. Beside of that, an artist knows his work is used by others and is not empowered to defend their rights due to the lack of knowledge of the artists about the law.

2. Protecting the creations of the creators, whether authors, artists, musicians, playwrights, sculptors, computer programmers, artists in the field of traditional weaving works.

\section{Legal protection}

1. A matter that protects legal subjects through applicable laws and regulations and enforces its implementation with a sanction.

2. Legal protection can be divided into 2 , namely:

a. Preventive Legal Protection, namely protection provided by the government with the aim of preventing violations before they occur.

b. Repressive legal protection, namely the final protection in the form of liability, fines, imprisonment, and additional penalties given if there is a dispute over the violation.

3. Copyright Protection System with the principle of automatic protection which states that copyright protection is given automatically without being based on certain formalities, such as registration of works or use of copyright notices, giving recognition that copyright appears automatically after the completion of the work in a certain form, without being required actions such as registration.

\section{Subhanale Woven Fabric as a Copyright}

The creation of a artwork requires a fairly long process. The creation of the work consists of several elements, namely ideas, forms (techniques), and appearances. These three elements are one of the factors behind the creator's creative work, because Subhanale woven fabric is an expression in the form of traditional patterns that always exist in a tradition in the Sukarara Village society, East Lombok Regency.

For this reason, it is necessary to have the expertise of the creator to be able to carry out copyrighted works that are protected by copyright. Subhanale woven creations were born with a distinctive shape that shows authenticity as the creation of an artist or figure of Sukarara village, East Lombok Regency.

The Importance of Subhanale's Copyright Protection

1. Encouraging and motivating the public to respect the rights of the creators for the creations they produce

2. Recognition of exclusive rights, namely the rights to enjoy the economic benefits of creations or inventions themselves, with the exception that other people without their consent cannot participate in enjoying the results of their creations.

3. The law protects and prevents others from taking unfair advantage of their creations

4. As an effort to preserve national culture.

Legal Protection of Subhanale Weaving Copyrights

1. Subhanale woven fabric is the original traditional work of Sukarara village, East Lombok Regency, which must be copyrighted to avoid any use or imitation by other parties without permission. Because creating is not something that is easy to do, so the existence of the creator requires an acknowledgment of both the society and the law as well as protecting, controlling and securing the community in the field of creation that must be registered, namely Subhanale woven fabric will be well protected as a medium for instilling cultural values.

Protection of Intellectual Property Rights on Subhanale woven fabric as a regional characteristic is based on:

First, the economic value

Second, the development of national character contained in traditional knowledge and folkfore (customs that become traditions in a culture).

Third, the unavoidable implementation of the Intellectual Property Rights system. 
For this reason, the law provides protection for Subhanale's woven fabrics and their works that were born from a process of creation regulated in Law Number 19 of 2002 concerning Copyright. This is in accordance with the entry of folkfore into Law No. 19 of 2002 concerning Copyright, because folkfore grows and develops from the ancestors passed down to the next generation through verbal and non-verbal ways, continuing until now.

2. The Regional Government of East Lombok Regency and the Sukarara society are trying to provide legal protection for Subhanale woven fabric so that there is no misuse of Copyright. Intellectual Property Rights itself consists of several rights that are closely related to the development of the traditional weaving industry

\section{Copyright and Traditional Cultural Expressions}

Woven fabric is one of the creations that is protected by copyright. Although not explicitly stated in the body of Law no. 28/2014 concerning Copyright, the "Subhanale woven fabric pattern" is explicitly stated in the Elucidation of Article 40 that "Creations that are protected include works in the fields of science, art, and literature, consisting of one of them a work of batik art or other patterns; IPR consists of a series of rights granted to protect creations produced by human thought. While Intellectual Property Rights are defined as the right to obtain legal protection of intellectual property in accordance with the laws and regulations in the field of Intellectual Property Rights, such as the Copyright Law, Patents, Industrial Designs, Trade Secrets, Plant Varieties, which are related to this activity more aimed at Subhanale woven fabric pattern that can be known who created it. For traditional woven fabric patterns that have long been known, used in tribal or ethnic textiles in the Sasak village, and whose creator is unknown, this kind of work is categorized as an expression of traditional culture and must pay attention to the values that live in the community that bears it. (Article 38 Copyright Law 2014). According to Article 58 (1), the copyright protection of Subhanale weaving works which protected in Article 40 letter $\mathrm{j}$ is for the creator's life length plus up to 70 years after the creator's death. Meanwhile, Article 38 (1) of the Copyright Law 2014 states, for Subhanale woven fabric which is included in the category of Traditional Cultural Expressions (EBT), the copyright holder is the State. Protection for Subhanale woven fabrics in the category of Traditional Cultural Expressions is granted indefinitely without a time limit (Article 60 paragraph 1 of the Copyright Law 2014) and obliges the State to take inventory, safeguard and maintain traditional cultural expressions (Article 38 paragraph 2). Furthermore, the use of traditional cultural expressions is required to pay attention to the values that live in the community that bears it (Article 38 paragraph 3 of the Copyright Law 2014). According to Article 38 paragraph 4 , further provisions regarding the copyright of traditional cultural expressions held by the State will be regulated by a Government Regulation (PP) which is mandated by the Copyright Law of 2014 is the same as the provisions of the Copyright Law number 19 of 2002 in the Third Part about Copyright on Works whose Author is Unknown in Article 10 paragraph 4 of Copyright Law 2002.

\section{Industrial Design}

According to the general provisions of Law number 31 of 2000 concerning industrial design (article 1 paragraph 1) it is stated that: Industrial Design is a creation of the shape, configuration, or composition of lines or colors, or lines and colors, or a combination in the form of three dimensions or two dimensions that give an aesthetic impression and can be realized in three-dimensional or two-dimensional patterns and can be used to produce a product, goods, industrial commodity, or handicraft. Industrial Design Rights are exclusive rights granted by the Republic of Indonesia to Designers for their creations to carry out their own creations for a certain period of time, or give their approval to other parties to exercise these rights. Those who are entitled to obtain the Right to Industrial Design are the Designers or those who receive such rights from the Designers. (Article 6 paragraph 1)

Industrial design is another branch of IPR that provides protection to the weaving industry. But unlike copyright which protects fine art, industrial design rights are granted to a work of use art. Woven fabric patterns that are mass-produced using the printing method at the factory are objects of industrial design protection in accordance with the definition of industrial design in Article 1 paragraph 1 of Law no. 31 of 2000. Unlike copyright which does not require registration as a condition of protection, according to Article 5 paragraph 1 of the Industrial Design Law 2000 , industrial designs are protected through registration for 10 years from the time the application is submitted to the Directorate General of Intellectual Property Rights. Article 2 paragraph 1 of the Industrial Design Law 2000 requires the existence of an element of novelty for a work to receive industrial design protection. These new terms are different from the original requirements that were requested for copyright protection. Although many woven designs produced today contain traditional patterns, if the creator adds new elements then the work can be protected by industrial designs (Sinaga, 2012).

\section{Trade Secret}

Knowledge of the manufacturing techniques and natural dyeing processes of Subhanale woven fabrics, including equipment, (such as canting and various printed pattern plates) is the subject of trade secret protection, which is in accordance with the provisions of Article 2 paragraph 1 of Law no. 30 of 2000 concerning Trade Secrets. Article 3 paragraph 4 states that trade secret protection is given to information that has an economic value and is kept confidential by the owner. Unlike 
making batik cloth which is more popularly known to the public, including people outside Indonesia, the making of Subhanale weaving with natural dyeing techniques is still not widely known. Therefore, it is very important for the Sasak customs to maintain this information of economic value so that the uniqueness of their ikat weaving is not imitated by outsiders, because it is the Sasak society themselves and their descendants who know.

\section{Brand}

Every business, whether small or large, needs a brand to support the marketing of its products. A brand is a sign that distinguishes goods or services belonging to other parties in a trade (Saidin, 2004). In addition, the brand also guarantees the quality of an item or service that is different from others (Saidin, 2004). A brand has an important meaning for the marketing of a product and if it is developed properly, a brand has a higher value than the assets of a business entity (Sinaga, 2012). According to Article 35 paragraph 1 of the Law on Marks and Geographical Indications no. 20 of 2016 (UUM 2016), brand protection is granted for 10 years after the date of brand application receipt. Furthermore, Article 35 paragraph 2 states that this protection can be extended for the same period of time. Currently, many Subhanale weaving craftsmen do not yet have a legally protected brand to market their products. This is because the subhanale craftsmen does not have enough knowledge about the importance of brands for a business. Like Small and Medium Enterprises (SMEs) in the batik industry in general (Sinaga, 2014), Subhanale weaving craftsmen also feel that the brand registration process is complicated, costs a lot of money, and takes a long time (in the question and answer session of the organizers in the activity).

\section{Geographical Indication (GI)}

Geographical Indications (GI) can prevent the misuse of the ikat products by foreign parties because Article 22 (2a) of the Trade Related Aspects of Intellectual Property Rights Agreement (TRIPS) guarantees protection from the use of GI that misleads the public as the geographical origin of an item. Then, GI protection can be used as an action against fraudulent competition as stated in Article 22 paragraph 2b of TRIPS (Rangnekar, 2003). In Indonesia, Geographical Indications are regulated in Articles 53-62 of the Brand Law 2016. In Article 53 of the 2016 UUM it is stated that the protection of Geographical Indications is given to institutions that represent the society in certain geographical areas and the provincial or district/city government that cultivates an item and/or products in the form of natural resources; handicraft items; or industrial products. Geographical Indications may be given for ikat weaving products, either machine-processed or handwoven. Article 53 paragraph 1 of the 2016 Brand Law stipulates that the protection of Geographical Indications for the weaving industry is obtained through a registration system. Only institutions that can register Geographical Indications represent the community in the geographical location of making Subhanale woven fabric and the provincial or city/district government. Subhanale woven fabric can be categorized as an institution that represents the society in a geographical location as stated in Article 53 paragraph 2 of the 2016 Brand Law. However, the Sasak indigenous people still have difficulty in registering the protection of Geographical Indications in Indonesia. Counseling activities for Intellectual Property Rights as a continuation will cooperate with local universities as academics who are expected to be able to assist in matters related to regulations for the preparation of materials to be submitted for completeness of IPR proposals, of course also accompanied by the relevant authorities in accordance with their fields.

\section{CONCLUSION}

Legal counseling activities on IPR to the Sasak Community have been going well, although the results cannot be felt directly, but it can be seen that the members of this weaving group already know that their Subhanale woven fabric is a creative work with high economic value, so it deserves protection of Intellectual Property Rights in copyright or traditional cultural expression, brands, industrial design, trade secrets and GI. However, they are still unable to register their woven fabric for brand protection, industrial design, and GI, due to limited funds, knowledge, and access. For this reason, there is a need for further assistance from the Regency Government regarding this Intellectual Property Rights issue.

\section{ACKNOWLEDGEMENT}

We would like to thank all those who have provided assistance for this activity, namely: 1). The head of Sukarara Village and his staff, 2). The head of the Sukarara hamlet who has given permission to carry out activities in the Sukarara village area and his traditional village who has provided assistance in the form of licensing, assistance, and accommodation in the organization of the activities, 3). The Dean of the Faculty of Law, Diponegoro University who has provided administrative facilities in the form of activities license for carrying out this activity.

\section{REFERENCES}

Saidin, O.K. (2004). Aspek hukum hak kekayaan intelektual (Cetakan ke-4). PT Raja Grafindo Perkasa.

Sinaga, V.S. (2012). Utilisation of intellectual property rights by Indonesian small medium enterprises: A case study of challenges facing Batik and Jamu industries (unpublished doctoral dissertation). University of Wollongong, Wollongong, Australia.

Sinaga, V.S. (2014) Faktor-Faktor Faktor-Faktor Penyebab Rendahnya Penggunaan Hak Kekayaan Intelektual 
di Kalangan Usaha Kecil Menengah Batik. Jurnal Hukum Ius Quia Iustum, 21 (1), 61-80. https://doi. org/10.20885/iustum.vol21.iss1.art4

The Trade Related Aspects of Intellectual Property Rights (TRIPS)

UU No. 30 tahun 2000 tentang Rahasia Dagang
UU No. 31 tahun 2000 tentang Desain Industri

UU No. 19 tahun 2002 tentang Hak Cipta

UU No. 28 tahun 2014 tentang Hak Cipta

UU No. 20 tahun 2016 tentang Merek dan Indikasi Geografis 